\title{
A New Variety of Salvia sericeotomentosa (Lamiaceae) from South Anatolia, Turkey
}

\author{
Ferhat Celep, Musa Doğan, Safi Bagherpour, and Ahmet Kahraman \\ Department of Biological Sciences, Middle East Technical University, 06531 Ankara, Turkey. \\ fcelep@metu.edu.tr; doganm@metu.edu.tr
}

Abstract. Salvia sericeotomentosa Rechinger f. (Lamiaceae) was first collected by A. Eig and M. Zohary in 1932 and was described in 1952 by K. H. Rechinger, but since that time it has not been collected again from its type locality. Among specimens collected from the Amanos Mountains near Hatay Province, Turkey, in 2006, the taxon was rediscovered on the basis of two different populations growing at low altitudes. These populations provide the type for the new variety $S$. sericeotomentosa var. hatayica Celep \& Dogan, which differs from the typical variety by having densely sericeous-tomentose and short glandular-pilose inflorescences. A full description of the new variety is also provided, as well as its conservation assessment.

Key words: Hatay Province, IUCN Red List, Salvia, Turkey.

The first revision of Salvia L. (Lamiaceae) in Turkey was made by Hedge (1982a) in Davis' Flora of Turkey and the East Aegean Islands, in which 86 species were recognized. Since 2005, extensive field surveys and laboratory studies have been conducted on Salvia in Turkey by the authors. These studies revealed two additional new species, $S$. marashica İlçim, Celep \& Doğan (İlçim et al., 2009) and S. ekimiana Celep \& Doğan (Celep \& Doğan, 2009); two new records, $S$. viscosa Jacquin (Celep et al., 2009) and S. macrosiphon Boissier (Kahraman et al., 2009); and now one additional new taxon is also recognized.

The type of Salvia sericeotomentosa Rechinger $\mathrm{f}$. was collected by A. Eig and M. Zohary from northern Hatay Province in Turkey in 1932 and described as a new species by K. H. Rechinger in 1952 (Rechinger, 1952). Hedge (1982a) later accepted this species as a local endemic growing in the Mediterranean region of Turkey. Between 2005 and 2006, the authors visited the type locality of $S$. sericeotomentosa as well as a number of other sites where it might potentially occur. Despite these expeditions, $S$. sericeotomentosa was not found from its type locality or the surrounding area. Our field and herbarium surveys have indicated that the species has not been collected since the original type collection. Specimens identified to this species were collected by the authors from the Amanos Mountains above Samandağ from southern Hatay Province in Turkey in 2006. These specimens were first identified with the keys provided by Hedge (1982a) in Davis' Flora of Turkey and the East Aegean Islands and other relevant floras, including Rechinger (1952, 1963), Flora Iranica (Hedge, 1982b), and Flora of Cyprus (Hedge, 1985). They were crosschecked with the collections cited in the flora as well as material housed at various herbaria (AEF, ANK, BM, E, G, GAZI, HUB, ISTE, ISTF, K, and W). After careful examination, some specimens had a distinctive, densely sericeous-tomentose and glandularpilose indument on their inflorescences, while all remaining material had glabrous inflorescences. Rechinger's (1952) protologue noted a glabrous inflorescence, and this has been confirmed by our examination. Our field observations demonstrated that both glabrous and pubescent populations may occur in the same locality, and it therefore seems reasonable to treat these as different varieties.

In Rechinger's 1952 protologue, flower color and seed characteristics were not properly indicated for Salvia sericeotomentosa, probably due to lack of proper material. Therefore, a full description of the new variety is given here on the basis of firsthand observations made in the field and herbarium.

1. Salvia sericeotomentosa Rechinger f., Oesterr. Bot. Z. 99: 52. 1952. TYPE: Turkey. Hatay: Achagi Zarkoun [Aşağı Zorkun], Amanus, ascent to Achagi Zarkoun, from the Karakisieh side, 800-1000 m, 30 June 1932, A. Eig \& M. Zohary s.n. (holotype, S; isotypes, E, HUJ).

1a. Salvia sericeotomentosa var. sericeotomentosa.

1b. Salvia sericeotomentosa var. hatayica Celep \& Doğan, var. nov. TYPE: Turkey. Hatay: Samandağ to Arsuz, among Quercus coccifera shrubs, $36^{\circ} 12^{\prime} 734^{\prime \prime} \mathrm{N}, 35^{\circ} 51^{\prime} 218^{\prime \prime} \mathrm{E}, 20-50 \mathrm{~m}$, 19 June 2007, F. Celep 1232 \& G. Akgül (holotype, GAZI; isotypes, ANK, E, K, MO). Figure 1. 


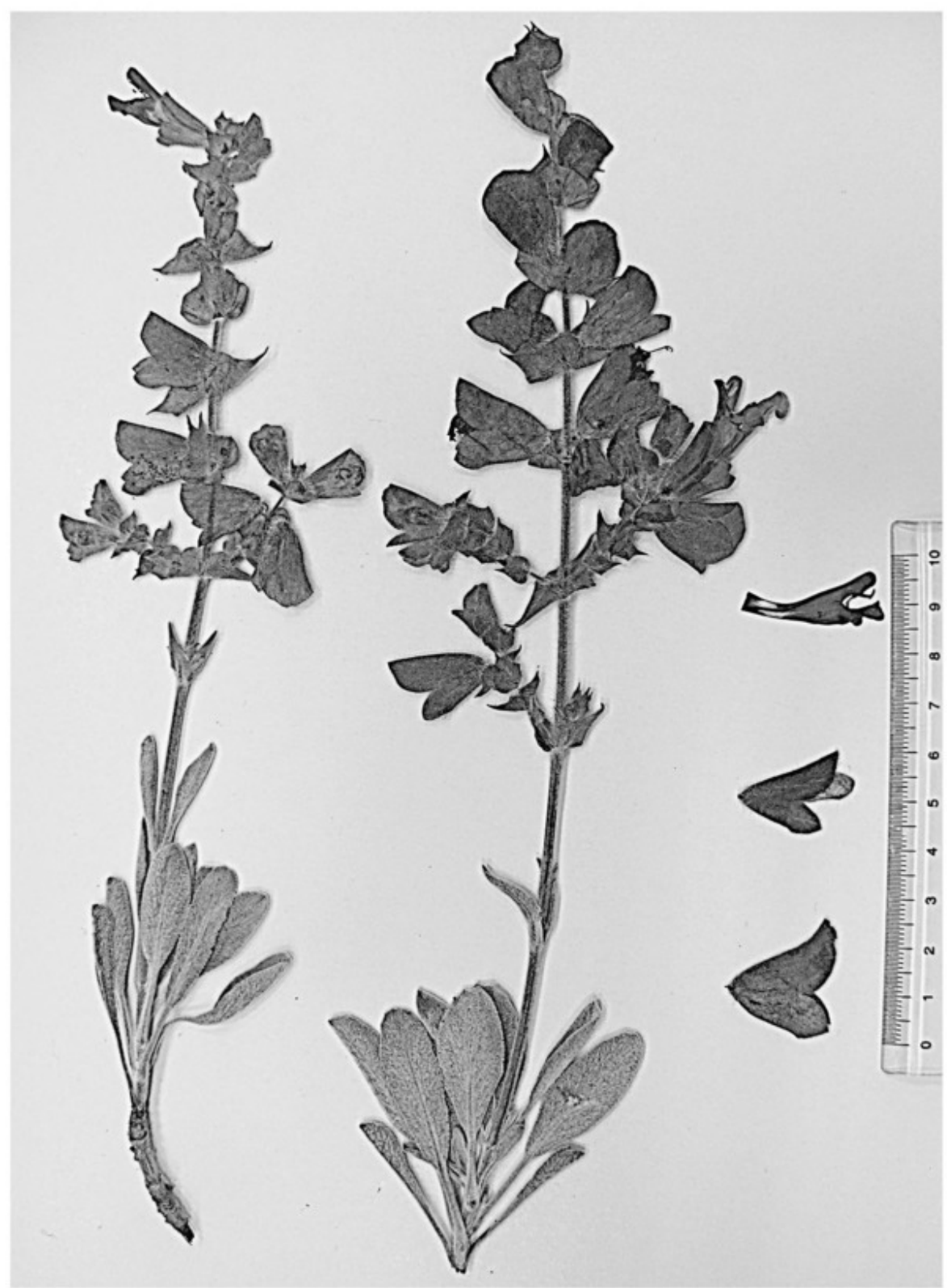

Figure 1. Fertile habit of Salvia sericeotomentosa var. hatayica Celep \& Doğan. Photo from the holotype F. Celep 1232 (GAZI).

Haec varietas a Salvia sericeotomentosa var. sericeotomentosa inflorescentia dense sericeo-tomentosa et breviter glanduloso-pilosa differt.

Perennial suffruticose herb; stems ascending, erect, 20-70 cm, with a densely sericeous-tomentose and short glandular-pilose indument with sessile glands. Leaves simple, mostly basal, oblong or oblong to lanceolate, $10-60 \times 6-18 \mathrm{~mm}$, densely sericeoustomentose and short glandular-pilose with sessile glands, attenuate at base, margins minutely crenulate, petiole $0.5-3 \mathrm{~cm}$. Verticillasters 2- to 4-flowered, distant; bracts broadly ovate to cordate, acuminate, 5$20 \times 5-20 \mathrm{~mm}$, green or green to purplish green; pedicels $3-7 \mathrm{~mm}$. Calyx membranous, green to purplish green, eglandular-tomentose and short glandular-pilose with sessile glands, broadly campanulate,
12-22 $\mathrm{mm}$, broadening and expanding to $30 \mathrm{~mm}$ in fruit, upper calyx lip entire; corolla white to cream with yellow upper lip, 25-32 mm, corolla tube ca. 20$23 \mathrm{~mm}$, slightly curved and widening toward throat, upper corolla lip \pm straight; stamens 2, staminal connectives shorter than filaments; style white, glabrous, 20-25 mm. Nutlets globose to ovoid, dark brown to black, ca. 3-4 × 2-3.2 mm, surface slightly tuberculate.

Distribution and ecology. The two varieties are both known from Hatay Province in southern Anatolia, Turkey. Field and literature studies showed that Salvia sericeotomentosa var. sericeotomentosa was confined to open fields within Pinus L. forest at altitudes of $800-1000 \mathrm{~m}$ in its type locality in the 


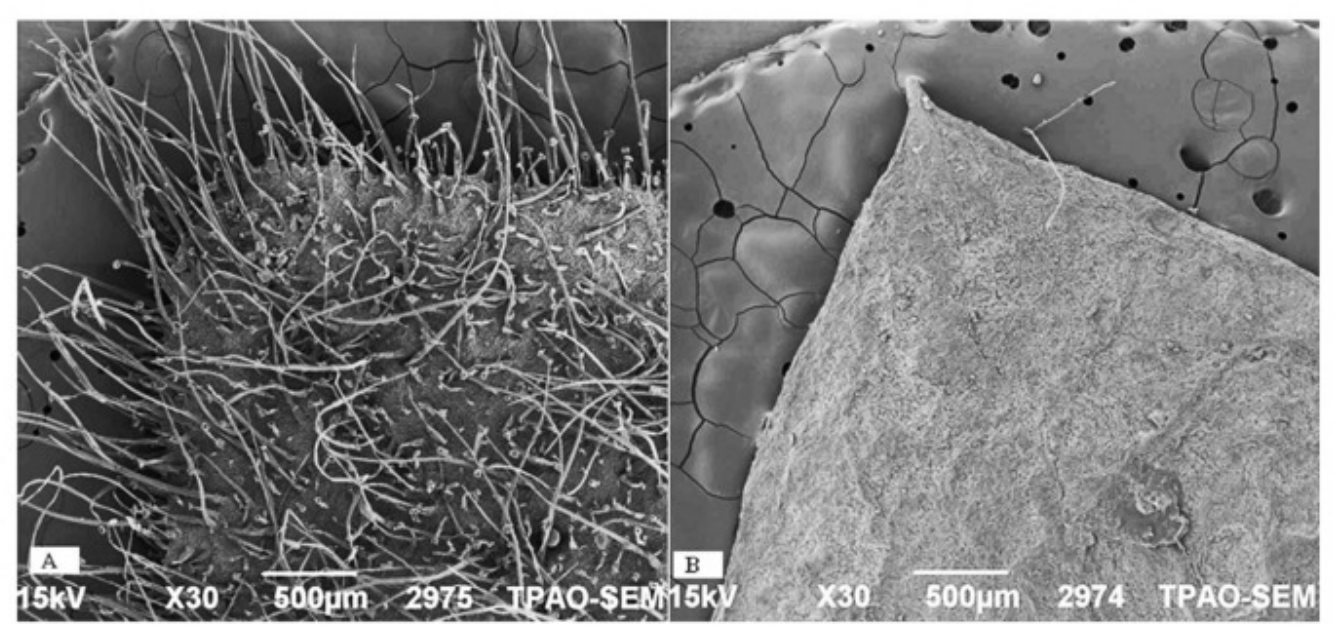

Figure 2. SEM images of calyx tips. - A. Salvia sericeotomentosa var. hatayica Celep \& Doğan. —B. Salvia sericeotomentosa Rechinger f. var. sericeotomentosa. A from F. Celep 1232 (GAZI); B from F. Celep 1402 (ANK).

northern Amanos Mountains. The new variety and the autonymic variety have now been collected from rocky mountain slopes in association with Quercus coccifera L., Pinus brutia Tenore, Cistus L., Centaurea L., and Pistacia L. shrubs in the southern Amanos Mountains at lower altitudes of $20-50 \mathrm{~m}$, thus extending the altitudinal range of the species from $20-1000 \mathrm{~m}$.

IUCN Red List category. Despite recent expeditions, Salvia sericeotomentosa has not been found in its type locality. It is known only from the present localities, and its estimated area of occupancy is less than $100 \mathrm{~km}^{2}$ with a population of less than 2000 individuals. According to our field observations, habitat destruction through human encroachment such as road construction, urbanization, and fire are the principal threats in the area. Therefore, the species should be considered Endangered (EN), according to IUCN Red List criteria (IUCN, 2001).
Etymology. The varietal epithet is derived from Hatay Province, the area where the new variety was first collected.

Notes. The new variety differs from the autonymic variety in its densely sericeous-tomentose and glandular-pilose inflorescences (Fig. 2, Table 1).

Paratypes. TURKEY. Hatay: Samandag to Arsuz, $36^{\circ} 12^{\prime} 734^{\prime \prime} \mathrm{N}, 35^{\circ} 51^{\prime} 218^{\prime \prime} \mathrm{E}, 25$ July 2006, S. Bagherpour \& F. Celep $1197 b$ (ANK); Samandag to Arsuz, $36^{\circ} 12^{\prime} 736^{\prime \prime} \mathrm{N}$, $35^{\circ} 51^{\prime} 218^{\prime \prime} \mathrm{E}, 19$ June $2007, F$. Celep 1232 (ANK); Arsuz to Samandag, $36^{\circ} 13^{\prime} 393^{\prime \prime} \mathrm{N} 35^{\circ} 50^{\prime} 711^{\prime \prime} \mathrm{E}, 2$ May $2008, G$. Akaydin \& F. Celep 1403 (ANK).

Acknowledgments. We wish to thank the curators of herbaria AEF, ANK, BM, E, G, GAZI, HUB, ISTE, ISTF, K, and W for allowing us to study their Salvia collections and the Scientific and Technical Research Council of Turkey (TUBITAK-TBAG-104 T 450) for their financial assistance.

Table 1. Morphological comparison of Salvia sericeotomentosa var. sericeotomentos and S. sericeotomentosa var. hatayica.

\begin{tabular}{|c|c|c|c|}
\hline & Variety sericeotomentosa ${ }^{1}$ & Variety sericeotomentos $a^{2}$ & Variety hatayica $^{3}$ \\
\hline Leaf indumentum & $\begin{array}{l}\text { densely sericeous-tomentose and } \\
\text { short glandular-pilose }\end{array}$ & $\begin{array}{l}\text { densely sericeous-tomentose and } \\
\text { short glandular-pilose }\end{array}$ & $\begin{array}{l}\text { densely sericeous-tomentose } \\
\text { and short glandular-pilose }\end{array}$ \\
\hline Inflorescence axis & glabrous & glabrous & $\begin{array}{l}\text { densely sericeous-tomentose } \\
\text { and short glandular-pilose }\end{array}$ \\
\hline Calyx & glabrous & glabrous & $\begin{array}{l}\text { sericeous-tomentose and short } \\
\text { glandular-pilose }\end{array}$ \\
\hline Corolla & - & $\begin{array}{l}\text { white to cream with yellow upper } \\
\text { lip }\end{array}$ & $\begin{array}{l}\text { white to cream with yellow } \\
\text { upper lip }\end{array}$ \\
\hline Altitude (m) & $800-1000$ & $20-50$ & $20-50$ \\
\hline
\end{tabular}

\footnotetext{
${ }^{1}$ Studied from the isotype A. Eig \& M. Zohary s.n. (E).

${ }^{2}$ Studied from $F$. Celep $1402 a$ (ANK).

${ }^{3}$ Studied from the holotype $F$. Celep 1232 (GAZI).
} 


\section{Literature Cited}

Celep, F. \& M. Doğan. 2009. Salvia ekimiana (Lamiaceae), a new species from Turkey. Ann. Bot. Fenn. (in press).

- \& A. Duran. 2009. A new record for the Flora of Turkey: Salvia viscosa Jacq. (Labiatae). Turk. J. Bot. 33: 57-60.

Hedge, I. C. 1982a. Salvia L. Pp. 400-461 in P. H. Davis (editor), Flora of Turkey and the East Aegean Islands, Vol. 7. Edinburgh University Press, Edinburgh. 1982b. Salvia L. Pp. 403-476 in K. H. Rechinger (editor), Flora Iranica 150. Akademische Druck und Verlagsanstalt, Graz.

1985. Salvia L. Pp. 1287-1299 in R. D. Meikle (editor), Flora of Cyprus, Vol. 2. Royal Botanic Gardens, Kew, Richmond.
İçim, A., F. Celep \& M. Doğan. 2009. Salvia marashica (Lamiaceae), a new species from Turkey. Ann. Bot. Fenn. 46(1): 75-79.

IUCN. 2001. IUCN Red List Categories and Criteria, Version 3.1. Prepared by the IUCN Species Survival Commission. IUCN, Gland, Switzerland, and Cambridge, United Kingdom.

Kahraman, A., F. Celep \& M. Dogan. 2009. A new record for the Flora of Turkey: Salvia macrosiphon Boiss. (Labiatae). Turk. J. Bot. 33: 53-55.

Rechinger, K. H. 1952. Labiatae novae orientalis. Österr. Bot. Z. 99: 52.

1963. Zur Flora von Syrien, Libanon und den angrenzenden Gebieten der Türkei. Ark. Bot. 5(1): $374-375$. 


\section{$2 \mathrm{BHL}$ Biodiversity Heritage Library}

Celep, Ferhat et al. 2009. "A New Variety of Salvia sericeotomentosa (Lamiaceae) from South Anatolia, Turkey." Novon a journal of botanical nomenclature from the Missouri Botanical Garden 19, 432-435.

View This Item Online: https://www.biodiversitylibrary.org/item/124658

Permalink: https://www.biodiversitylibrary.org/partpdf/121946

\section{Holding Institution}

Missouri Botanical Garden, Peter H. Raven Library

\section{Sponsored by}

Missouri Botanical Garden

\section{Copyright \& Reuse}

Copyright Status: Permission to digitize granted by rights holder Rights: https://www.biodiversitylibrary.org/permissions

This document was created from content at the Biodiversity Heritage Library, the world's largest open access digital library for biodiversity literature and archives. Visit BHL at https://www.biodiversitylibrary.org. 